\title{
SPAWNING ACTIVITY IN NODILITTORINA EXIGUA AND PEASIELLA ROEPSTORFFIANA (LITTORINIDAE, GASTROPODA)
}

\author{
AUTHOR(S): \\ Ohgaki, Shun-ichi
}

\section{CITATION:}

Ohgaki, Shun-ichi. SPAWNING ACTIVITY IN NODILITTORINA EXIGUA AND PEASIELLA ROEPSTORFFIANA (LITTORINIDAE, GASTROPODA). PUBLICATIONS OF THE SETO MARINE BIOLOGICAL LABORATORY 1981, 26(4-6): 437-446

\section{ISSUE DATE:}

1981-09-30

URL:

http://hdl.handle.net/2433/176028

RIGHT: 


\title{
SPAWNING ACTIVITY IN NODILITTORINA \\ EXIGUA AND PEASIELLA ROEPSTORFFIANA (LITTORINIDAE, GASTROPODA) ${ }^{1)}$
}

\author{
SHUN-ICHI OHGAKI \\ Seto Marine Biological Laboratory, Kyoto University
}

With Text-figures $1-6$

\begin{abstract}
Periodicity in spawning was studied for the two species of Littorinidae, Nodilittorina exigua and Peasiella roepstorffiana at Shirahama, Wakayama Pref. Breeding season of $N$. exigua is summer, active spawning being associated with strong waves and not with spring tides. Egg release is active at around high tides in the field and this habit is preserved for some time in the laboratory. Peasiella roepstorffiana also spawns in summer and its active spawning is related to both lunar phase and daily tidal cycle. The difference in spawning habit is related to the difference in the distribution height of these species under the influence of the tidal regime in upper littoral zone.
\end{abstract}

\section{Introduction}

Nodilittorina exigua (Dunker, 1890) is a very common species on seashore rocks above high tide mark around the Seto Marine Biological Laboratory (Shirahama, Wakayama Pref., Japan). This species has been called by different names: Littorina exigua by Mitsukuri (1901), Tectarius granularis by Hukuda (1950) and Nodilittorina granularis by Habe (1956) and Kojima (1960); the present species name Nodilittorina exigua is adopted according to Rosewater (1970) and Habe (personal communication).

Though $N$. exigua is a common species in Japan, little work has been done on breeding biology of this species. Only the informations available are on the shape and size of the egg capsule described by Habe (1956) and on spawning season in summer reported by Kojima (1960). Detailed study on spawning activity, particularly in relation to lunar phase or daily tidal cycle, is lacking. As for world Littorinidae, lunar or semi-lunar periodicity in spawning is suggested or confirmed by Lysaght (1941), Struhsaker (1966), Borkovski (1971), Berry and Chew (1973), Gallagher and Reid (1974), Grahame (1975), Schmitt (1979), Fish (1979), Alifierakis and Berry (1980) and Hughes and Roberts (1980). Negative result is obtained by Pilkington (1971). Information on daily tidal variation in spawning is rather scarce. Struhsaker (1966) and Gallagher and Reid (1974) suggested spawning at high tides, while Schmitt (1979) described that it primarily occurred on rising higher high tides.

1) Contributions from the Seto Marine Biological Laboratory, No. 677.

Publ. Seto Mar. Biol. Lab., XXVI (4/6), 437-446, 1981.

(Article 24) 
In this report, seasonal, lunar and daily tidal variation in spawning activity in $N$. exigua are described. Especially detailed study was made on the daily tidal variation in spawning in the field, which has not been investigated intensively so far. During the course of the research, egg capsules of Peasiella roepstorffiana which inhabits the zone a little lower than that of $N$. exigua were also collected and its spawning activity is compared with that of $N$. exigua.

\section{Methods}

Field observation and collection were conducted at the place named Do-mon near the laboratory during the period from March 1979 to December 1980. Here $N$. exigua lives on rock in the zone from +110 to $+210 \mathrm{~cm}$ in height (spring high tide usually around $+190 \mathrm{~cm}$ ). $P$. roepstorffiana inhabits the lower zone, from +80 to $+150 \mathrm{~cm}$.

Close-shore plankton sampling was made to collect newly released egg capsules in order to analyse spawning time. A surface water sample was taken at a site close to the shore with water depth of about $50 \mathrm{~cm}$ (Fig. 1) and 40 liter sea water

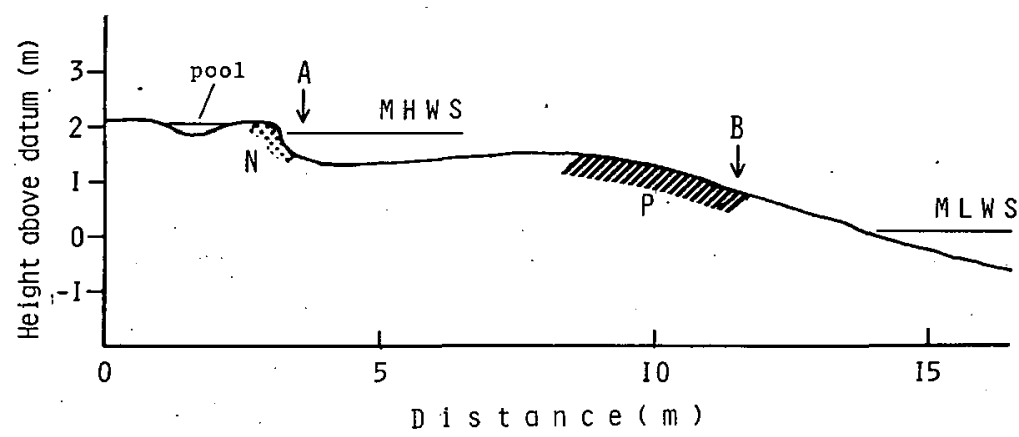

Fig. 1. A cross section of the sampling site, Do-mon. The dotted area indicates the distribution range of Nodilittorina exigua $(\mathrm{N})$ and the hatched area that of Peasiella roepstorffiana (P). A, sampling spot when water level is high. $\mathrm{B}$, sampling spot when water level is low. MHWS, mean high water of spring. MLWS, mean low water of spring.

was filtered through $95 \mu$ mesh gauze in the field. To know the period of spawning in $N$. exigua, sampling was made at spring high tide during the study period. Air and water temperatures were measured at the same time. Sampling at day and night high tide time were also made every day during one month period in the first year and at one week intervals during two months in the breeding season in the second year. Additional samples were collected at $30 \mathrm{~min}$. intervals during $5 \mathrm{hr}$ period around high tides on three days of different tidal states ranging from spring to neäp tide.

For the laboratory spawning experiment snails were taken from Do-mon during low tide and females were selected (males can be distinguished by their large pennis). 
Fifty females of $N$. exigua collected were kept each in a small glass bottle $(3 \mathrm{~cm}$ in diameter, $5 \mathrm{~cm}$ in height) which contained filtered sea water. The bottles were changed every $1.5 \mathrm{hr}$ so that the egg capsules released during $1.5 \mathrm{hr}$ periods can be examined. Females sometimes crawled up out of water but all of the fifty snails were immersed at least at the starting point of every $1.5 \mathrm{hr}$ period. The observation was continued for $24 \mathrm{hr}$ at temperature of $27^{\circ} \mathrm{G}$ and salinity of $34.1 \%$.

All the samples both from the field and the laboratory were fixed immediately in $5 \%$ formalin. Later they were concentrated to 5 or $10 \mathrm{ml}$ and subsamples of 1 or $1.5 \mathrm{ml}$ were taken up from them onto a glass to count the number of egg capsules. In the field samples, egg capsules of several species of Littorinidae appeared and they were distinguished and identified according to the description by Habe (1956).

\section{Results}

\section{Spawning of Nodilittorina exigua}

Females of $N$. exigua were observed in the laboratory to release intermittently one or a few egg capsules at a time. Spawning was observed only when females were in sea water or at water surface and released egg capsules came at once to float in the water and sank onto the bottom. Capsules were not adhesive to the substratum and instantly drifted again when the water in the bottle was stirred by shaking.

Rock surfcae of about $0.1 \mathrm{~m}^{2}$ area where $N$. exigua were abundant was washed by fresh water during low water period on 24 June 1979 at spring tide (downward arrow in Fig. 8) and washing was gathered and examined. No egg capsule was found in it although many capsules were floating in the sea at previous high tides.

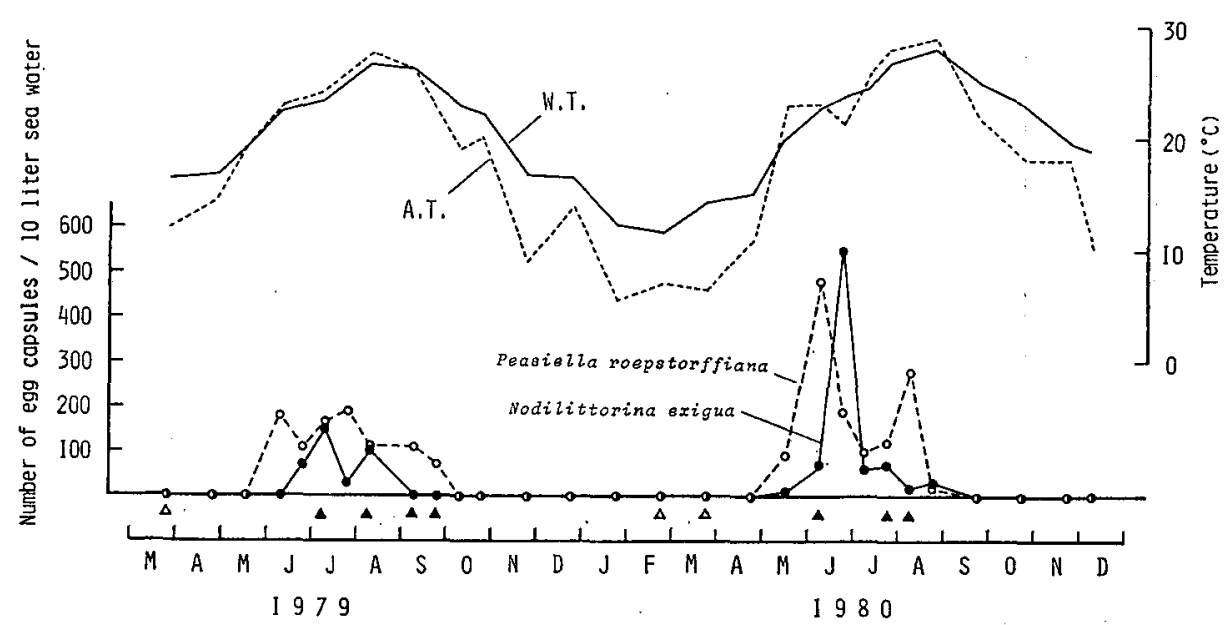

Fig. 2. Seasonal occurrence of egg capsules in close-shore plankton with monthly fluctuation of air temperature (A.T.) and water temperature (W.T.). Samples were taken at spring high tides and measurements of air and water temperature were made at the same time. The solid and open triangles above the symbols of months indicate the occurrence of egg capsules of Nodilittorina millegrana and Littorina brevicula respectively. 

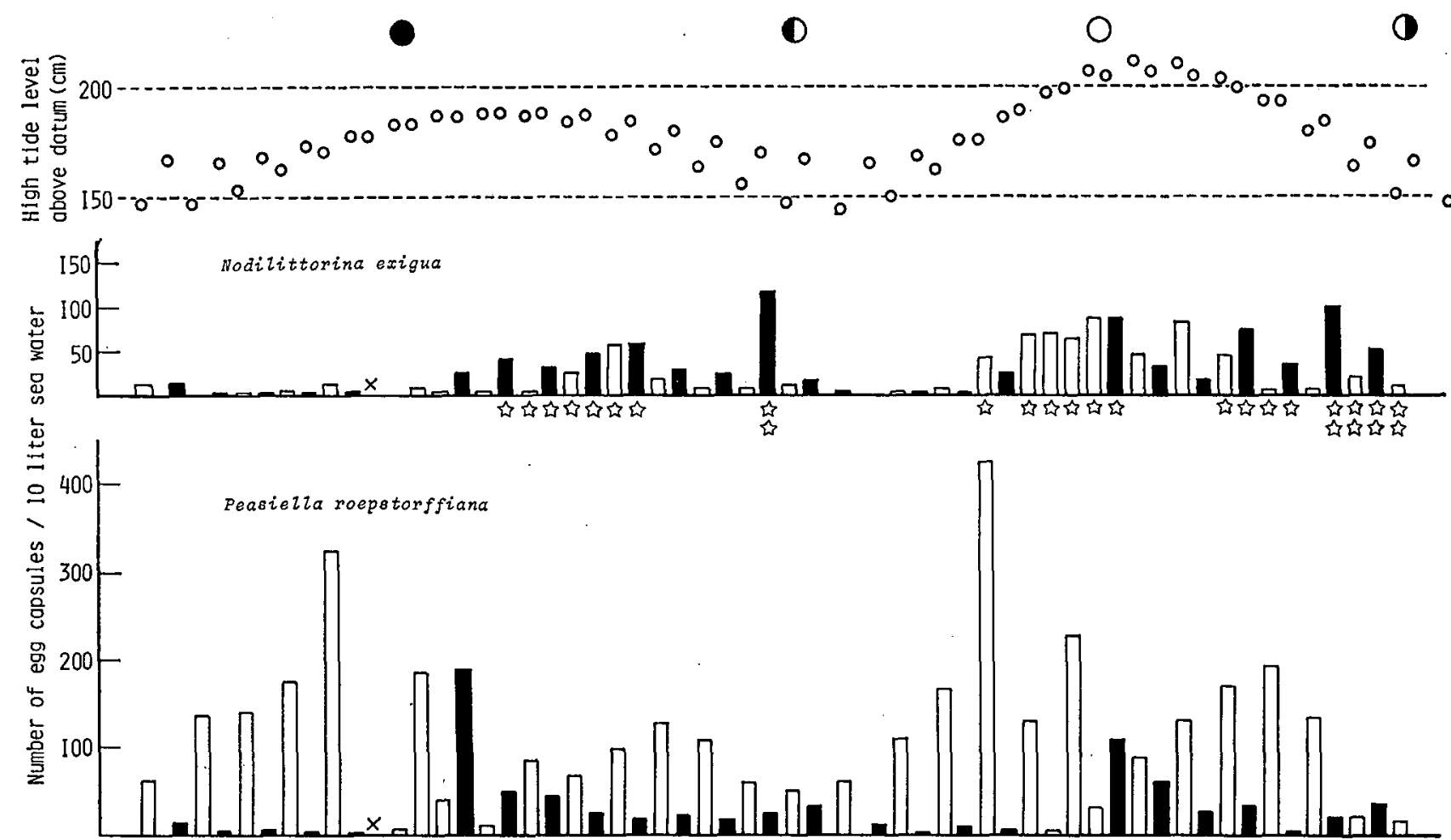

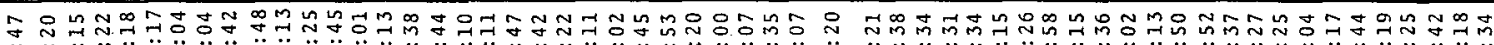
Time 作

Date
$18 \quad 19^{\circ} 20 \quad 21 \quad 22$
$2324 \quad 25$
$\begin{array}{lllll}28 & 29 & 30 & 31 & 1\end{array}$
234
56
$\begin{array}{llll}7 & 8 & 9 & 10\end{array}$

Fig. 3. The numbers of collected egg capsules of Nodilittorina exigua and Peasiella roepstorffiana at successive high tides with high tide levels and lunar phases from 18 July to 16 August. Open bars indicate the samples in the daytime (5:00-19:00) and solid bars at night (19:00-5:00). Single star means the occurrence of strong waves and double stars mean that of extremely strong waves which swept over the tide pool shown in Fig.1. $\quad$, Sample was lost. 
These laboratory and field results suggest that egg capsules are not deposited on emersed rock but are spawned directly into the sea to drift.

Spawning Periodicity

\section{(1) Spawning Season}

Seasonal variation in occurrence and abundance of egg capsules of the four littorinids, Nodilittorina exigua, Nodilittorina millegrana, Littorina brevicula and Peasiella roepstorffiana in the close-shore plankton samples are shown in Fig. 2. Among them those of $N$. exigua and $P$. roepstorffiana were abundant. Judging from the period of occurrence of egg capsules, it may be safely said that $N$. exigua breeds from middle June to early September but mainly in June and August, $P$. roepstorffiana from May to September, $N$. millegrana in summer and $L$. brevicula in early spring.

(2) Fortnight Periodicity

Lunar or semi-lunar periodicity in the fluctuation of the number of collected egg capsules is obscure in $N$. exigua (Fig. 3). Spawning appears to be ocurring more or less throughout the breeding period but abundant occurrence is recorded on the day when waves are strong. The difference in number of egg capsules between spring and neap tide was examined under calm sea condition before the influence of typhoon appeared (Fig. 4) but again the difference was not clear except around 29-30 June at full moon.

In $P$. roepstorffiana a marked fluctuation in the number of egg capsules was found in close-shore plankton samples (Fig. 3). The number of egg capsules collected is

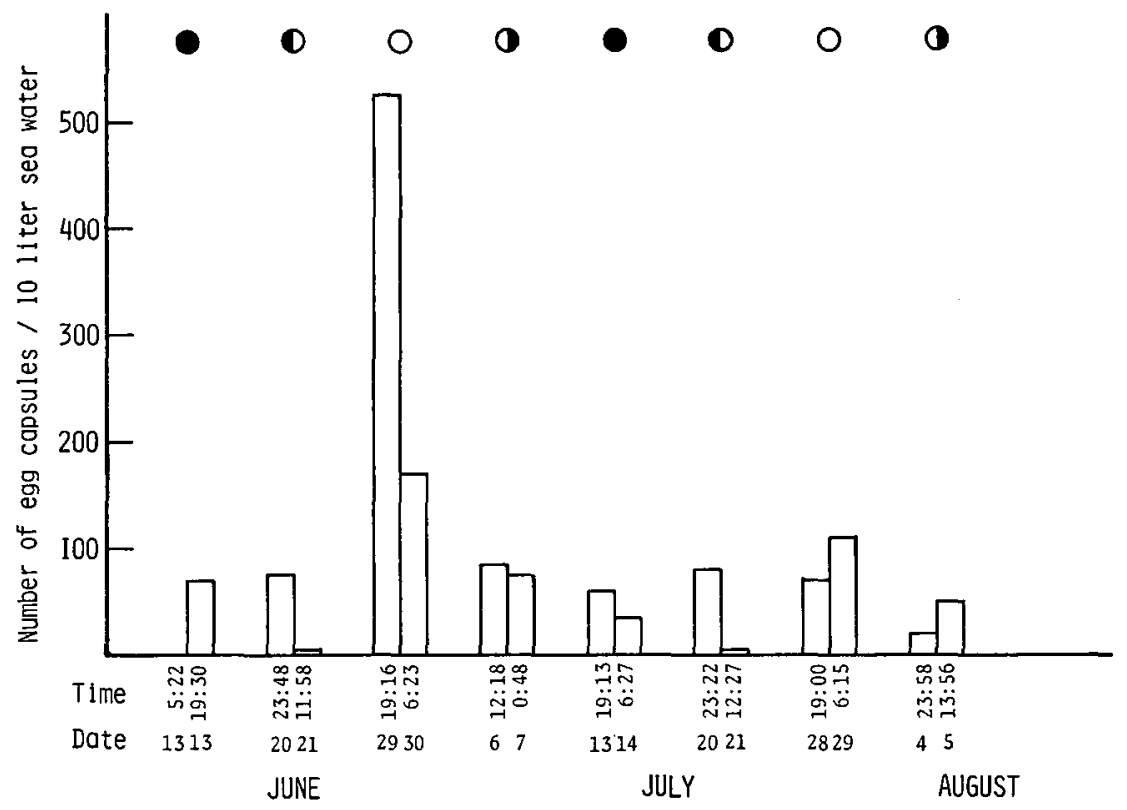

Fig. 4. The numbers of collected egg capsules of Nodilitiorina exigua at successive spring and neap tides from 13 June to 5 August 1980. The sea was calm throughout the study period and no star mark is plotted. 

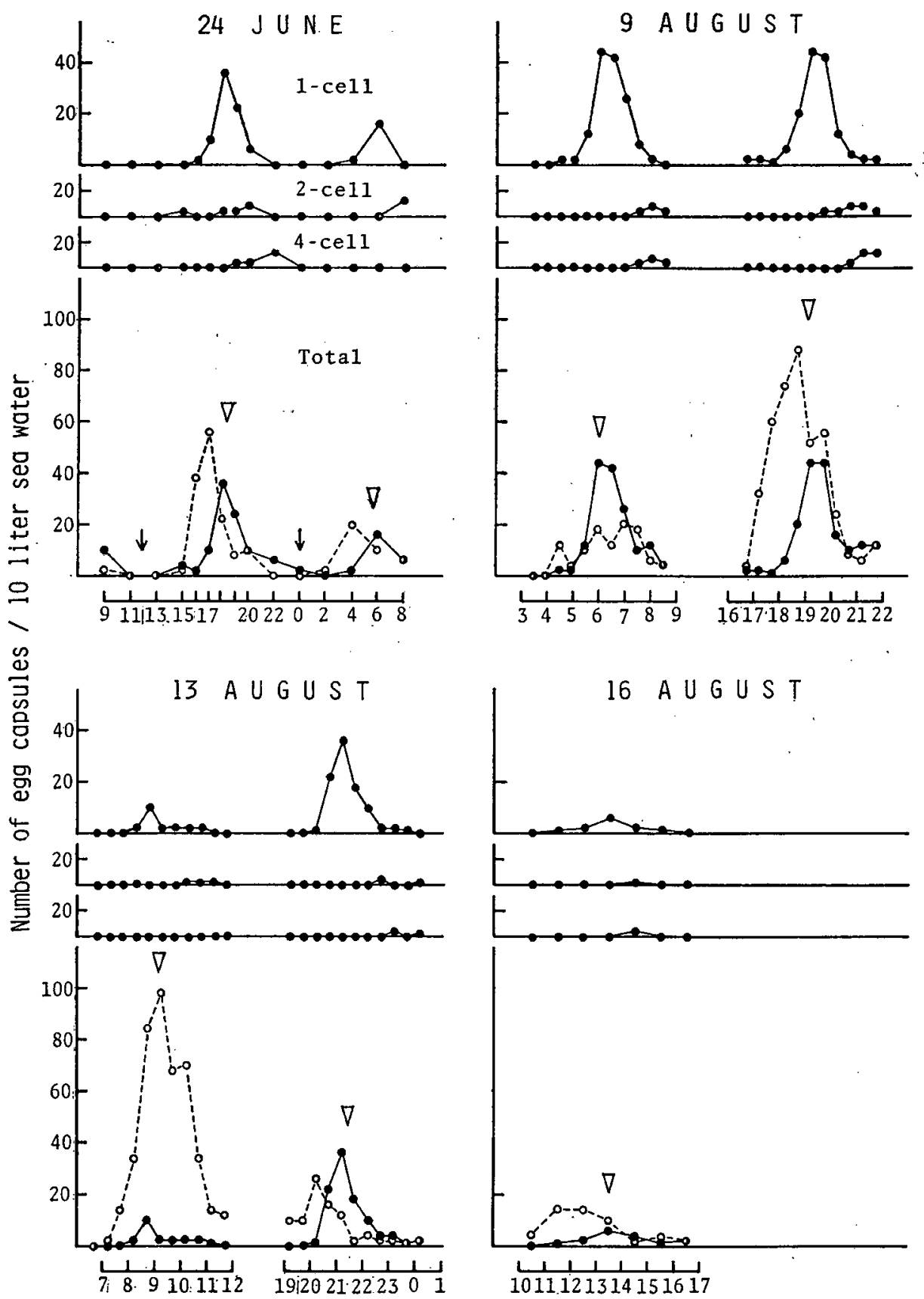

T i m e

Fig. 5. Daily tidal variation in the number of collected egg capsules of Nodilittorina exigua (solid circles) and Peasiella roepstorffiana (open circles) on 24 June (spring tide, new moon), 9 August (spring tide, full moon), 13 August and 16 August (neap tide). Number of egg capsules of $N$. exigua containing eggs of different cleavage stages are shown separately. "Total" includes more advanced stages other than 1- to 4-cell stages. Downward arrow indicates the time when rock surface was examined for egg capsules. $\nabla$, Time of high tide. 
generally larger in daytime than at night. The daytime collection attains to a large peak during the period from neap to spring tide and a small peak from spring to neap tide, showing a fall at spring and neap tides. On the contrary, the number of egg capsules collected at night are abundant both at spring and neap tides and no other peaks are clearly discernible. There are no increases and decreases in the number that can be related to the days of strong waves.

(3) Daily Tidal Periodicity

The fluctuation in the number of egg capsules in close-shore plankton samples collected at $30 \mathrm{~min}$. or $1 \mathrm{hr}$ intervals during $24 \mathrm{hr}$ period or $5 \mathrm{hr}$ period around high tide time is shown in Fig. 5. The egg capsules of $N$. exigua are distinguished into different cleavage stages and their numbers are also separately shown. The number of egg capsules reaches a peak around high tide time in both two species on four days ranging from spring to neap tide. Egg capsule number of 1-cell stage of $N$. exigua shows sharp peak at the time of high tide with low peaks of 2-cell and 4-cell stages following in succession. The peak of $P$. roepstorffiana occurs a little earlier than that of $N$. exigua in general.

Laboratory observation on the early development of $N$. exigua showed that newly spawned eggs were all at 1-cell stage, and 1-3 hr after spawning, most of them developed into 2- to 4-cell stages. The lapses of time between two peaks of successive two stages in the field collection are approximately consistent with this result.

Fifty females were observed in the laboratory during $24 \mathrm{hr}$ from 10 to 11 August
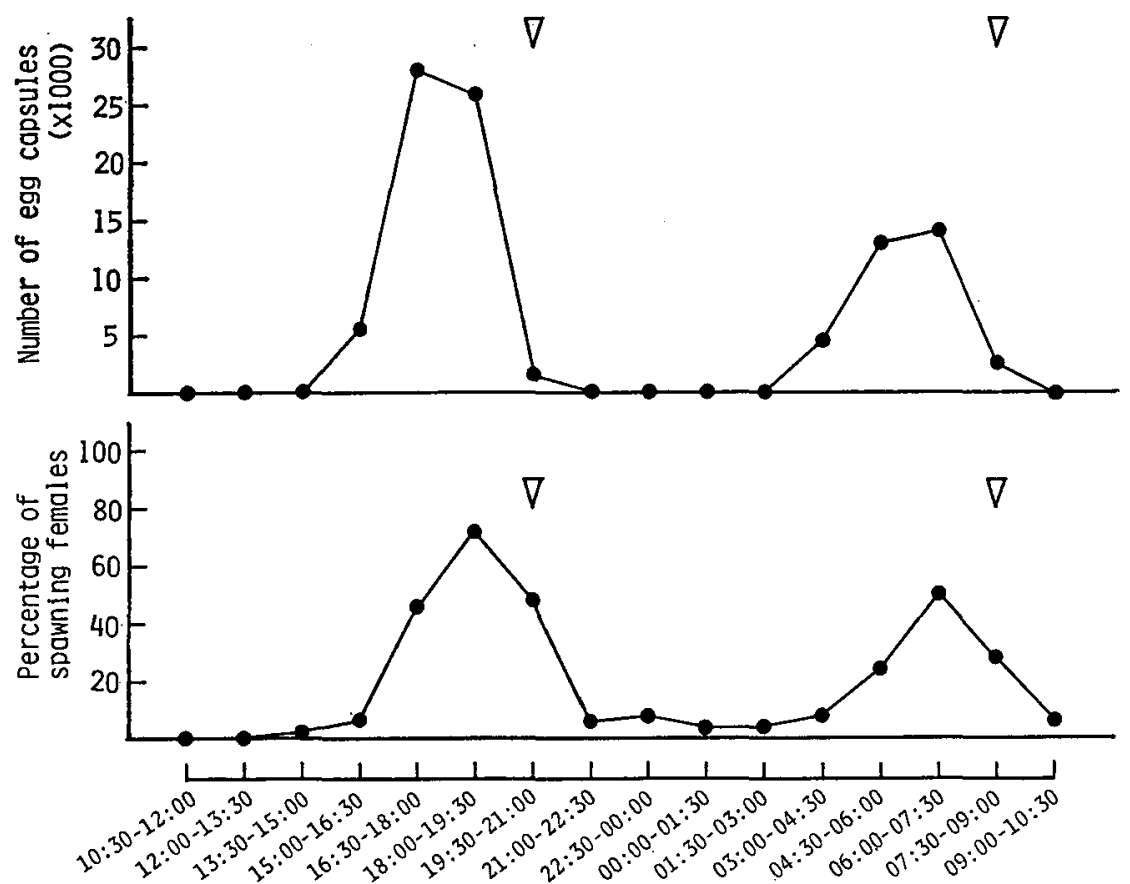

Fig. 6. Result of laboratory spawning experiment for Nodilittorina exigua which was continued for $24 \mathrm{hr}$ from 10 to 11 August 1979. $\nabla$, Time of high tide. 
(spring tide) to know the time and rhythmicity in spawning (Fig. 6). Total number of egg capsules spawned and percentage of spawning females were examined in successive $1.5 \mathrm{hr}$ periods. The peaks of these values appeared during the rising high tide phase even under the laboratory conditions without tidal influence.

\section{Discussion}

Kojima (1960) reports that $N$. exigua breeds in summer from July to August at Asamushi. In the present study this species is also confirmed to spawn in summer mainly from July to August at Shirahama. According to Rosewater (1970), Asamushi is nearly at the northern end of the geographical distribution of this species and Shirahama locates in the middle part of the range. In Littorina littorea, it is known that the breeding season varies geographically, which is suggested to be related to temperature condition (Smith and Newell, 1955). This is not the case with $N$. exigua and such temperature difference as between Asamushi and Shirahama, annual mean sea temperatures in 1972 being $14.2^{\circ} \mathrm{C}$ and $20.4^{\circ} \mathrm{C}$ respectively, does not seem to affect the breeding season of this species.

$N$. exigua does not exhibit a clear lunar periodicity in spawning, which has been reported for many species of Littorinidae. Instead, active spawning in this species occurs when waves are strong. In the Australian littoral fringe periwinkles Melarapha cincta and Melarapha oliveri, the presence of egg capsules of both species in rock pool samples is associated with rough seas but not with spring tides (Pilkington, 1971). As $N$. exigua inhabits supra-littoral zone but can only spawn in sea iwater, it may be adaptive to be ready to spawn whenever its habitat is washed by waves or immersed in sea water. $P$. roepstorffiana, on the other hand, shows a marked spawning periodicity which appears to be correlated with lunar phase. This species inhabits a lower zone than $N$. exigua and its habitat is always immersed at high tides regardless of wave action. This may be a background of the preservation of their spawning periodicity which is not disturbed by temporal rough sea conditions.

Daily tidal periodicity in spawning is detectable in $N$. exigua both in the field and in the laboratory. As the majority of eggs develop into 2- to 4-cell stages within $3 \mathrm{hr}$ after spawning, the peak of the number of capsules containing l-cell stage eggs in Fig. 5. indicates that active spawning is occurring around the time of the peak which is approximately coincident with high tide time. Even when the snails are kept immersed in sea water in a bottle where they cannot perceive directly the tide, spawning does not occur during the period that coincides with low tide time. This suggests that they have at least a short term memory for the time at which the tide will be highest. Spawning in $P$. roepstorffiana seems to occur a little earlier than in $N$. exigua, which may be due to that this species inhabits a lower zone than $N$. exigua and that its habitat is immersed earlier than that of $N$. exigua at rising tide.

The difference between high tide and low tide level at around spring tide is nearly two meters so that the immersion timing of the habitat of $N$. exigua is critically determined by daily tidal cycle and is rarely influenced by wave condition. On 
the other hand, high tide level of spring tide is around $+190 \mathrm{~cm}$ and that of neap tide $+140 \mathrm{~cm}$ while $N$. exigua inhabits the zone from +110 to $+210 \mathrm{~cm}$ and such difference of $50 \mathrm{~cm}$ is easily exceeded by strong waves. This may be the reason that $N$. exigua shows daily tidal periodicity in spawning, particularly at around spring tide, and that the difference in spawning activity between at spring and neap tide is not detected in the field. However, under calm sea condition, the distribution zone of $N$. exigua is immersed more in the spring tide period than in the neap tide period at high tide, and this is expected to be reflected in the amount of egg capsules released from immersed females. The result of 1980 (Fig. 4) is opposed to this, showing no difference of spawning activity between at spring and neap tide in most cases. This suggests that contraction of the immersion range of the habitat around neap tide is compensated by some mechanism and the population is always able to release considerable number of egg capsules into the sea.

\section{Summary}

1) Spawning activity of the littoral fringe periwinkle, Nodilittorina exigua was studied by close-shore plankton sampling and laboratory observation from March 1979 to December 1980 at Shirahama.

2) Spawning season of this species was summer, from middle June to early September but mainly from July to August at Shirahama.

3) High spawning activity correlated with spring tides was not observed but strong waves accelerated spawning in the field population.

4) Spawning was suggested to occur at around high tide in the field and this habit was preserved in the laboratory at least for $24 \mathrm{hr}$ without tidal influence.

5) In the close-shore plankton samples, egg capsules of Peasiella roepstorffiana also appeared in summer. This species showed lunar periodicity in spawning and released egg capsules were most abundant on rising high tide phase.

6) The difference in the distribution height of the two species was suggested to reflect on the difference in the spawning habit under the influence of the tidal regime in upper littoral zone.

\section{Acknowledgement}

I would like to express my thanks to Prof. E. Harada of the Seto Marine Biological Laboratory for his helpful discussions and critical reading of the manuscript. Thanks are also due to Dr. M. Imafuku, Dr. Y. Maruyama and Mr. K. Wada of Kyoto University for their reading the manuscript. Mr. K. Takenouchi of Kyoto University who kindly took some plankton samples when the author was absent in the Laboratory is also gratefully acknowledged. 


\section{S. OHgaki}

\section{REFERENCES}

Alifierakis, N.S. and Berry, A.J. 1980. Rhythmic egg-release in Littorina littorea (Mollusca: Gastropoda). J. Zool. Lond., 190: 297-307.

Berry, A.J. and Chew, Eunice 1973. Reproductive systems and cyclic release of eggs in Littorina melanostoma from Malayan mangrove swamps (Mollusca: Gastropoda). J. Zool., Lond., 171: 333-344.

Borkovski, T.V. 1971. Reproduction and reproductive periodicity of south Floridian Littorinidae (Gastropoda: Prosobranchia). Bull. Mar. Sci., 21 : 826-840.

Fish, J.D. 1979. The rhythmic spawning behaviour of Littorina littorea (L.). J. moll. Stud., 45: $172-177$.

Gallagher, S.B. and Reid, G.K. 1974. Reproductive behaviour and early development in Littorina scabra angulifera and Littorina irrorata. (Gastropoda: Prosobranchia) in the Tampa Bay region of Florida. Malacological Review, 7: 105-125.

Grahame, J. 1975. Spawning in Littorina littorea (L.) (Gastropoda: Prosobranchia). J. exp. mar. Biol. Ecol., 18: 185-196.

Habe, T. 1956. The floating egg capsules of the Japanese periwinkles. Venus, 19(2): 117-121. (in Japanese with English summary)

Hughes, R.N. and Roberts, D.J. 1980. Growth and reproductive rates of Littorina neritoides (L.) in North Wales. J. mar. biol Ass. U.K., 60: 591-599.

Hukuda, H. 1950. The movement of the snail, Tectarius granularis (Gray) on a stone wall in relation to ebb and flow. Physiology and Ecology Japan, 4: 92-101. (in Japanese with English summary)

Kojima, Y. 1960: On the reproduction of periwinkles, Littorinidae, Gastropoda. Bull. Mar. Biol. Sta. Asamushi, 10(2): 117-120.

Lysaght, A.M. 1941. The biology and trematode parasites of the gastropod Littorina neritoides on the Plymouth breakwater. J. mar. biol. Ass. U.K., 25: 41-67.

Mitsukuri, K. 1901. Negative phototaxis and other properties of Littorina as factors in determining its habitat. Annot. Zool. Japan, 4: 1-19.

Pilkington, M.C. 1971: Eggs, larvae and spawning in, Melarapha cincta (Quay \& Gaimard) and $M$. oliveri Finley (Littorinidae, Gastropoda). Aust. J. Mar. Freshwater Res., 22; 79-90.

Rosewater, J. 1970. The family Littorinidae in the Indo-Pacific I, The subfamily Littorininae. IndoPacific Mollusca, vol. 2 no. 11: 417-506.

Schmitt, R.J. 1979. Mechanics and timing of egg capsule release by the littoral fringe periwinkle Littorina planaxis (Gastropoda: Prosobranchia). Mar. Biol., 50: 359-366.

Smith, J.E. and Newell, G.E. 1955. The dynamics of the zonation of the common periwinkle (Littorina littorea) on a stony beach. J. Anim. Ecol., 24: 35-56.

Struhsaker, J.W. 1966. Breeding, spawning, spawning periodicity and early development in the Hawaiian Littorina: L. pintado (Wood), L. picta (Phillippi) and L. scabra (Linne). Proc. malac. Soc. Lond., 37: 137-166. 